\title{
PERSEPSI REMAJA TERHADAP FAKTOR PENGHAMBAT PEMANFAATAN PELAYANAN KESEHATAN REPRODUKSI DI PUSKESMAS GAMBOK KABUPATEN SIJUNJUNG
}

\author{
Vella Dwi Yani ${ }^{1}$, Ova Emilia ${ }^{2}$, Hari Kusnanto ${ }^{3}$
}

\begin{abstract}
Background: Reproductive health service is an important component that has to be improved globally because teenagers often lack basic information about reproductive health. Despite the need for reproductive health service only a few teenagers utilize the service due to several constraints in having reproductive and sexual health service as a result of limited access to the service and negative perception about center of reproductive health service. Data of Sijunjung District Health Office Sumatera Barat show that only $20 \%$ of teenagers utilize reproductive health service available. Whereas cases in teenagers indicate that $9.2 \%$ of teenagers have had premarital sexual intercourse and $40 \%$ are married at teenage period ( $<20$ years) and $10 \%$ is caused by unwanted pregnancy.

Objective: To study the perception of teenagers about physical, process, economic and psychosocial factors as obstacles in the utilization of reproductive health service.

Method: The study was observational with cross sectional design and descriptive quantitative approach that used qualitative data obtained from indepth interview. Subject of the study were students of SMU 1 and 2 of 1416 years old around the working area of Health Centers that have health service for teenagers with as many as 131 respondents.

Result and Discussion: Perception of teenagers about physical, process and economic factors showed that the majority had good perception so these factors were not obstacles for teenagers in utilizing reproductive health service. The majority of teenagers (68\%) had bad perception about psychosocial factor so this was an obstacle in the utilization of reproductive health service.

Conclusion: Obstacles in the utilization of reproductive health service at the health center were caused by psychosocial factor because of shame and unwillingness to tell the problem to staff that was considered as strangers. Teenagers also doubted the confidentiality of the problem they told to the staff.
\end{abstract}

Keywords: perception, teenagers, reproductive health, utilization

\begin{abstract}
ABSTRAK
Latar belakang: Pelayanan kesehatan reproduksi merupakan komponen penting yang harus diperbaiki secara global. Remaja sering kali kekurangan informasi dasar tentang kesehatan reproduksi. Meskipun kebutuhan pelayanan kesehatan reproduksi tinggi namun pemanfaatannya masih rendah karena berbagai hambatan memperoleh pelayanan dan juga adanya persepsi negatif terhadap pusat pelayanan kesehatan reproduksi. Data dari dinas Kesehatan kabupaten Sijunjung Sumatera Barat menunjukkan hanya 20\% remaja yang memanfaatkan pelayanan kesehatan reproduksi. Sedangkan kasus dan masalah kesehatan reproduksi menunjukkan $9,2 \%$ sudah berhubungan seks sebelum menikah, dan $40 \%$ menikah pada usia remaja (<20 tahun) serta 10\% mengakibatkan kehamilan tak dikehendaki.

Tujuan: Untuk mempelajari persepsi remaja terhadap faktor fisik, proses, ekonomi dan psikososial untuk memanfaatkan pelayanan kesehatan reproduksi remaja.
\end{abstract}

Pusat Kesehatan, Kabupaten Sijunjung

Bagian Obstetri dan Ginekologi, Fakultas Kedokteran UGM

. Program Pasca Sarjana Manajemen Sistem Informasi Kesehatan, Universitas Gadjah Mada 
Metode: Studi ini merupakan observasional rancangan potong lintang disertasi pengumpulan data kualitatif melalui wawancara mendalam.Subyek penelitian adalah siswa SMA kelas 1 dan 2 usia 14-16 tahun di wilayah kerja puskesmas sebanyak 131 responden.

Hasil dan Pembahasan: Mayoritas remaja memiliki persepsi baik terhadap faktor fisik, proses, dan ekonomi. Tiga faktor bukan merupakan penghambat memperoleh layanan kesehatan reproduksi. Sementara itu faktor psikososial dianggap sebagai penghambat (68\%) untuk memanfaatkan pelayanan kesehatan reproduksi.

Kesimpulan: Hambatan pemanfaatan layanan kesehatan reproduksi adalah faktor psikososial karena malu dan tidak percaya untuk menceritakan masalah pada petugas kesehatan yang tidak dikenal. Remaja juga meragukan kerahasiaan masalah yang diungkapkan.

Kata kunci: persepsi, remaja, kesehatan reproduksi, pemanfaatan

\section{PENDAHULUAN}

Sekitar $85 \%$ remaja hidup di negara berkembang dan sebesar 1,7 juta remaja meninggal setiap tahun pada usia 10-19 tahun karena kecelakaan, kekerasan dan komplikasi kehamilan. ${ }^{1}$ Penduduk di Indonesia yang berusia remaja (10-24 tahun) berdasarkan laporan dari Badan Pusat Statistik tahun 2009 adalah $27 \%$ dari total populasi. Terbatasnya pengetahuan tentang kesehatan reproduksi telah meningkatkan risiko kehamilan yang tidak diinginkan (unwanted pregnancy) yang dapat mengarah pada tindakan aborsi. Sebagian besar aborsi di Indonesia termasuk dalam kategori aborsi tidak aman, proporsi yang dilakukan oleh remaja perempuan sebesar $40 \%$ 50\%. Menurut data SKRRI tahun 2007 pada usia sebelum 15-24 tahun hanya $1 \%$ wanita yang pernah melakukan hubungan seksual dan $6 \%$ pada laki-laki belum dengan alasan rasa ingin tahu. ${ }^{2}$

Pelayanan kesehatan reproduksi bagi remaja merupakan komponen penting yang harus ditingkatkan oleh kesehatan secara global, karena remaja sering kali kekurangan informasi dasar mengenai kesehatan reproduksi. Banyak remaja yang kekurangan informasi mengenai ketersediaan sarana pelayanan kesehatan reproduksi. Hal tersebut karena bentuk pelayanan yag kurang ramah remaja dan sulitnya akses terhadap pelayanan kesehatan yang ada. ${ }^{3}$ Survei yang pernah dilakukan di Kabupaten Sijunjung pada tahun 2007, sebanyak 52,3\% pernah melakukan perilaku seksual yang berisiko, 9,2\%pernah melakukan hubungan seksual pranikah (sexual intercourse). Perkawinan yang terjadi pada usia di bawah 20 tahun sebanyak 40,6\% dan 10\% disebabkan oleh kehamilan yang tidak diinginkan (unwanted pregnancy) selama tahun $2008 .{ }^{4} \mathrm{Hal}$ ini disebabkan rendahnya pengetahuan remaja tentang kesehatan reproduksi dan kurangnya informasi tentang pentingnya kesehatan reproduksi.

Pemanfaatan pelayanan kesehatan reproduksi oleh remaja masih rendah, yang disebabkan oleh berbagai faktor diantaranya faktor fisik yaitu akses terhadap layanan, faktor finansial, faktor struktur sistem pelayanan dan faktor psikologi remaja itu sendiri. ${ }^{5}$ Beberapa penelitian kualitatif menunjukkan hambatan remaja untuk memanfaatkan layanan kesehatan reproduksi disebabkan karena biaya, sikap negatif petugas kesehatan dan kurangnya percaya diri remaja. ${ }^{6}$

Hasil penelitian yang lain mengemukakan bahwa remaja mempunyai persepsi bahwa pelayanan kesehatan reproduksi disediakan untuk orang yang sudah menikah atau untuk orang yang bermasalah, tidak untuk remaja pada umumnya. Hasil penelitian melaporkan $72 \%$ remaja mengaku takut diketahui oleh orang tua atau orang-orang yang mereka kenal sehingga menghalangi mereka untuk memanfaatkan pelayanan kesehatan reproduksi, sedangkan $67,8 \%$ karena perasaan malu untuk meminta pelayanan kesehatan reproduksi kepada petugas. ${ }^{7}$ 
Penelitian ini bertujuan untuk mengetahui persepsi remaja terhadap faktor penghambat pemanfaatan pelayanan kesehatan reproduksi dalam upaya meningkatkan kualitas pelayanan kesehatan peduli remaja (PKPR) di Puskesmas Gambok Kabupaten Sijunjung.

\section{METODE}

Penelitian ini menggunakan pendekatan deskriptif yang dilengkapi data kualitatif. Penelitian deskriptif dalam hal ini dimaksudkan untuk menggambarkan pendapat dan menghimpun fakta tentang persepsi remaja terhadap faktor penghambat pemanfaatan pelayanan kesehatan reproduksi. Pelaksanaan penelitian ini dilaksanakan di Kabupaten Sijunjung Sumatera Barat, pada siswa SMU 1 dan SMU 2 dengan sampel penelitian siswa telah berusia 14-16 tahun yang merupakan kelompok rawan dan harus mengetahui tentang kesehatan reproduksi. Kriteria inklusi dalam penelitian ini siswa laki-laki dan perempuan, tercatat sebagai siswa SMU kelas I dan II,dan bertempat tinggal di wilayah Kabupaten Sijunjung.

Teknik pemilihan sampel dengan proportional sampling. Besar sampel pada penelitian ini dihitung menggunakan rumus uji hipotesis untuk 1 proporsi. Jumlah sampel penelitian ini 131 siswa. Penelitian ini juga memakai data kualitatif dengan mewawancarai 4 orang informan terdiri dari siswa laki-laki dan perempuan. Instrumen dalam penelitian ini adalah kuesioner yang disusun oleh peneliti sendiri dengan mengacu pada penelitian yang dilakukan oleh Mmari \& Magnani di Lusaka, Zambia. ${ }^{8}$ Sedangkan panduan wawancara disusun oleh peneliti sendiri.

Analisis data menggunakan analisis deskriptif meliputi karakteristik responden dan persepsi remaja terhadap faktor yang menghambat pemanfaatan pelayanan kesehatan reproduksi yang meliputi faktor fisik, faktor proses, faktor ekonomi dan faktor psikososial. Analisis data kualitatif dilakukan untuk mendukung data kuantitatif.

\section{HASIL DAN PEMBAHASAN}

\section{a. Karakteristik Subjek Penelitian}

Karakteristik responden dilihat dari jenis kelamin, status tempat tinggal, jarak tempuh ke tempat pelayanan, jumlah uang saku per bulan, punya kendaraan sendiri, mengikuti ekstrakulikuler. Karakteristik orang tua dilihat dari pendidikan dan pekerjaan orang tua.

Tabel 1. Distribusi frekuensi karakteristik responden

\begin{tabular}{ccc}
\hline \multirow{2}{*}{ Karakteristik subjek } & \multicolumn{2}{c}{ Jumlah } \\
\cline { 2 - 3 } & $\mathrm{n}$ & $\%$ \\
\hline Jenis kelamin & 46 & 35.1 \\
$-\quad$ Laki-laki & 85 & 64.8 \\
$-\quad$ Perempuan & & \\
Status tempat tinggal & 87 & 66.4 \\
- Dengan orang tua & 14 & 10.6 \\
- Dengan keluarga lain & 30 & 22.9 \\
- Kost & & \\
Jarak tempuh ke tempat pelayanan & 57 & 43.5 \\
$-\quad<1 \mathrm{Km}$ & 37 & 28.2 \\
$-\quad 1-2 \mathrm{Km}$ & 15 & 11.4 \\
$-\quad>2-3 \mathrm{Km}$ & 10 & 7.6 \\
$-\quad>3-4 \mathrm{Km}$ & 12 & 9.1 \\
\hline$\quad>4 \mathrm{Km}$ &
\end{tabular}


Tabel 1. Distribusi frekuensi karakteristik responden (lanjutan)

\begin{tabular}{|c|c|c|c|}
\hline \multirow{2}{*}{\multicolumn{2}{|c|}{ Karakteristik subjek }} & \multicolumn{2}{|c|}{ Jumlah } \\
\hline & & $\mathbf{n}$ & $\%$ \\
\hline \multicolumn{4}{|c|}{ Jumlah uang saku per bulan } \\
\hline- & $<$ Rp.100.000 & 14 & 10.6 \\
\hline- & Rp.100.000-Rp.200.000 & 32 & 24.4 \\
\hline- & $>$ Rp.200.000-Rp.300.000 & 47 & 35.8 \\
\hline- & $>$ Rp.300.000-Rp.400.000 & 38 & 29.0 \\
\hline- & $>$ Rp.400.000 & - & - \\
\hline \multicolumn{4}{|c|}{ Mempunyai kendaraan sendiri } \\
\hline- & $\mathrm{Ya}$ & 56 & 42.7 \\
\hline- & Tidak & 75 & 57.2 \\
\hline \multicolumn{4}{|c|}{ Keikutsertaan ekstrakulikuler } \\
\hline- & Ya & 118 & 90.0 \\
\hline- & Tidak & 13 & 9.9 \\
\hline \multicolumn{4}{|c|}{ Pendidikan orang tua } \\
\hline- & Tidak sekolah & 1 & 0.7 \\
\hline- & SD & 13 & 9.9 \\
\hline- & SMP & 10 & 7.6 \\
\hline- & SMA & 46 & 35.1 \\
\hline- & PT & 61 & 45.6 \\
\hline \multicolumn{4}{|c|}{ Pekerjaan orang tua } \\
\hline- & Buruh/tani/nelayan/petani & 22 & 16.7 \\
\hline- & Pedagang & 19 & 14.5 \\
\hline- & PNS/ABRI & 75 & 57.2 \\
\hline- & Pegawai swasta & 15 & 11.4 \\
\hline
\end{tabular}

b. Persepsi Remaja Berdasarkan Faktor Fisik

reproduksi yang ada di puskesmas. Hampir seluruh yang Menghambat Pemanfaatan Pelayanan Kesehatan Reproduksi responden mempersepsikan mudah dicapai (91\%), dengan jarak tempuh tidak lebih dari 15 menit dan

Faktor fisik yaitu jarak yang ditempuh remaja dilalui transportasi umum dengan waktu tidak lebih dari tempat tinggal ke pelayanan kesehatan dari 30 menit

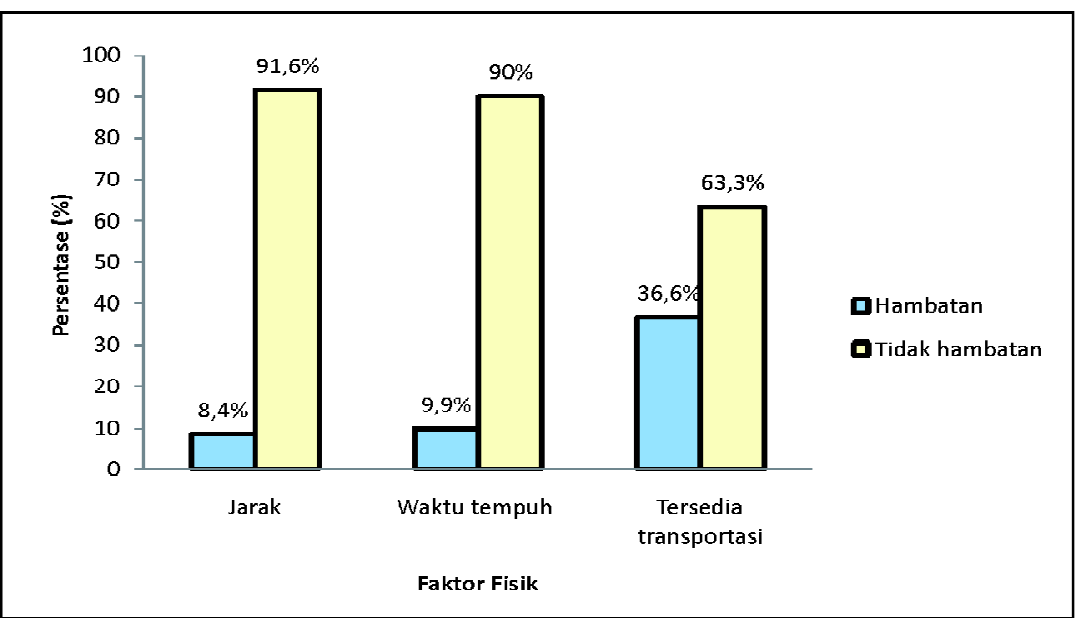

Gambar 1. Distribusi persepsi remaja berdasarkan faktor fisik sebagai penghambat pemanfaatan pelayanan kesehatan reproduksi 
Berdasarkan hasil wawancara mendalam pada remaja diketahui bahwa menurut persepsi mereka, jarak dari tempat tinggal ke pelayanan kesehatan yang ada dipuskesmas tidak jauh, dapat ditempuh dengan kendaraan, dilalui transportasi umum dan tidak memakan waktu yang lama. Remaja juga mengatakan bahwa jarak dari sekolah ke pelayanan kesehatan reproduksi juga tidak jauh, jadi menurut mereka jarak merupakan tidak menjadi hambatan bagi mereka untuk memanfaatkan pelayanan kesehatan reproduksi di puskesmas. Berikut ini adalah penuturan remaja mengenai hambatan faktor fisik:

".....dari rumah saya ke puskesmas nggak jauh, bisa jalan kaki aja buk...ya..bukan karena jauh atau dekatnya buk... mengapa saya tidak mau datang ke klinik remaja ..." (IP2)

"...saya rasa pelayanan kesehatan reproduksi yang ada di puskesmas tidak jauh dan mudah untuk dicapai, kalaupun ada temanteman yang tinggalnya jauh, mereka ratarata punya kendaraan sendiri kok..." (IL2) "........ menurut saya kalau jarak dari rumah ke puskesmas tidak jauh, rata-rata kami tinggal masih di wilayah puskesmas buk dan sepertinya bukan merupakan alasan untuk tidak datang ke pelayanan kesehatan reproduksi yang ada di puskesmas...". (IP1)

"....ya kalau rumah saya ke puskesmas nggak jauh buk.... Paling kalau naik motor nggak nyampek 2 menit kok...., bukan buk...bukan karena jarak yang bikin saya tidak pernah mengunjungi klinik remaja di puskesmas....." (IL1).

\section{c. Persepsi Remaja Berdasarkan Faktor Proses yang Menghambat Pemanfaatan Pelayanan Kesehatan Reproduksi}

Faktor proses atau pelayanan dengan konsep youth friendly yaitu sikap petugas yang ramah, penuh perhatian dan tidak menggurui dalam memberikan pelayanan kesehatan reproduksi terlihat hampir semua remaja mempunyai persepsi bahwa tidak ada hambatan dalam pemanfaatan pelayanan kesehatan reproduksi di puskesmas (79,3\%). Mayoritas remaja $(84,1 \%)$ mempunyai persepsi tidak ada hambatan dalam memanfaatkan prosedur pelayanan kesehatan reproduksi di puskesmas.

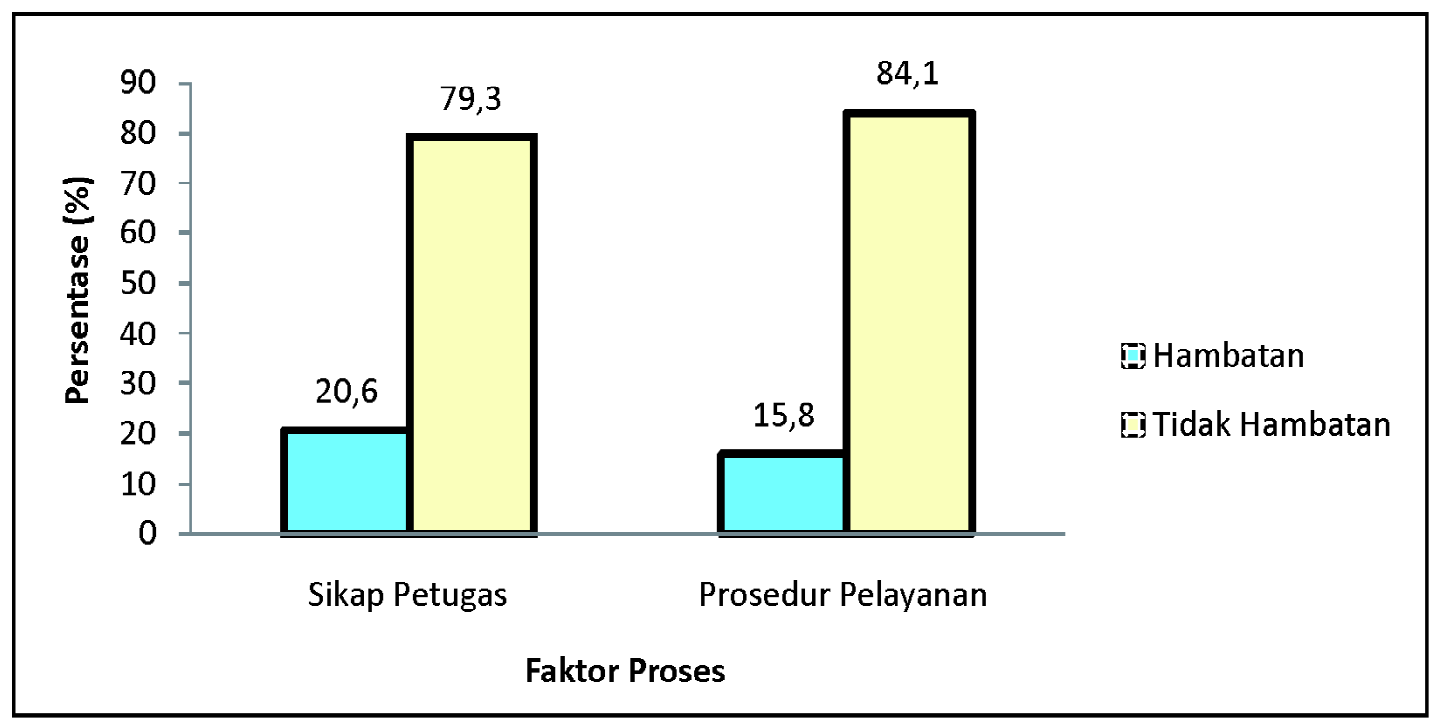

Gambar 2. Distribusi persepsi remaja berdasarkan faktor proses sebagai penghambat pemanfaatan pelayanan kesehatan reproduksi 
Lebih lanjut ditanyakan persepsi remaja mengenai sikap petugas dalam memberikan penyuluhan atau konseling kepada remaja. Menurut jawaban informan petugas yang ada di pelayanan kesehatan reproduksi cukup ramah dan baik, tetapi mereka masih enggan untuk mengungkapkan masalah mereka karena petugas masih dianggap orang yang belum mereka kenal dan belum bisa mereka percaya, seperti terungkap berikut ini:

"......kalau petugas puskesmas cukup ramah dan bersahabat...tapi saya masih takut untuk berkonsultasibuk.... ya...takut nanti masalah saya diceritakan ke orang lain..."(IP1)

"......Menurut saya petugas puskesmas adalah orang yang tidak begitu kita kenal, sehingga untuk menyampaikan masalah yang sifatnya agak pribadi ada perasaan malu dan tidak terbuka.... " (IL2)

".....saya nggak percaya buk...kalau masalah kita bisa dirahasiakan oleh petugas di puskesmas... dan saya juga takut buk kalau masalah saya diketahui orang lain...." (IP2)

".....saya tidak pernah ke puskesmas untuk berkonsultasi buk....., tapi saya rasa petugas yang ada disana cukup baik dan ramah, dilihat dari waktu petugas datang ke sekolah untuk memberikan penyuluhan ke pada kami....."(IL1)

Ketika ditanya bagaimana prosedur puskesmas dalam memberikan pelayanan, remaja mempunyai persepsi yang baik terhadap prosedur pelayanan

"....masalah prosedur pelayanan di puskesmas... menurut saya nggak lama dan juga nggak berbelit-belit......" (IP2)

"......menurut saya prosedur yang ada di puskesmas nggak terlalu ribet..." (IL2)

".......saya rasa prosedur yang harus dilalui dipuskesmas tidak terlalu sulit...., kita datang melapor pada bagian registrasi lalu langsung masuk ke ruang klinik remaja..., disana sudah ada petugas yang menunggu"(IP1).

\section{d. Persepsi Remaja Berdasarkan Faktor Ekonomi yang Menghambat Pemanfaatan Pelayanan Kesehatan Reproduksi}

Pada faktor ekonomi mayoritas remaja (71,7\%) setuju bahwa membayar bukan merupakan hambatan dalam memanfaatkan pelayanan kesehatan reproduksi dan hampir semua remaja $(93,8 \%)$ mempunyai persepsi bahwa tarif pelayanan juga tidak menjadi hambatan dalam memanfaatkan pelayanan kesehatan reproduksi di puskesmas.

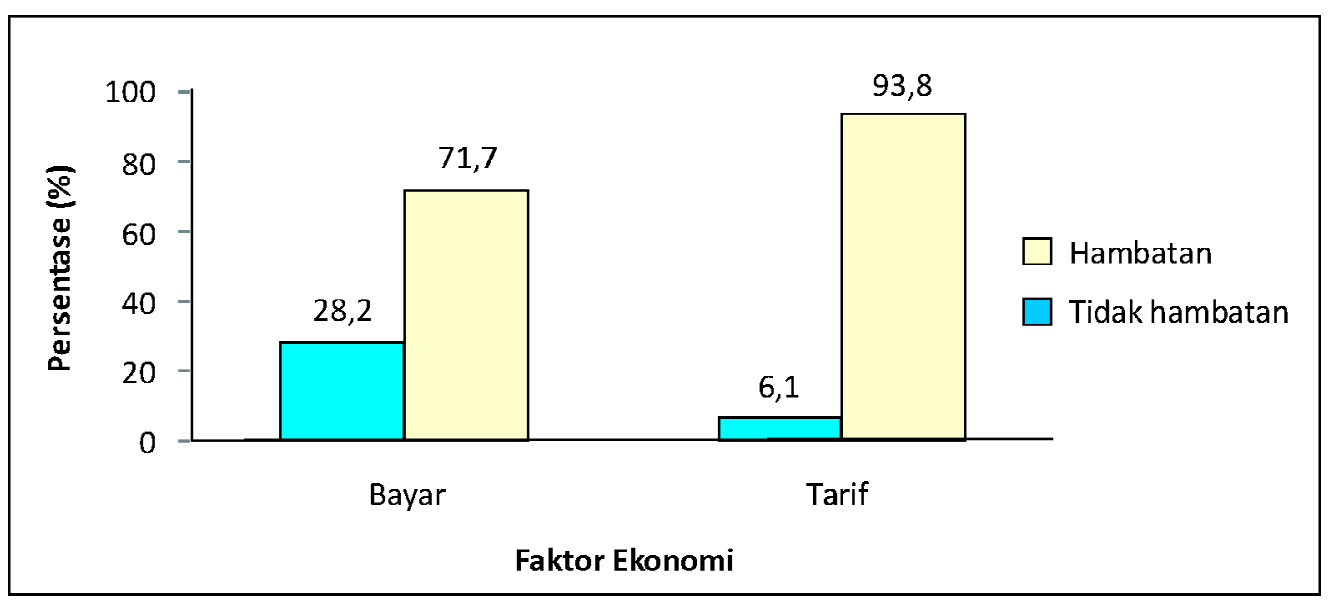

Gambar 3. Distribusi persepsi remaja berdasarkan faktor ekonomi sebagai penghambat pemanfaatan pelayanan kesehatan reproduksi 
Ketika informan ditanya apakah untuk mendapatkan pelayanan kesehatan reproduksi di puskesmas mereka harus membayar, sebagian informan berpendapat tidak membayar tetapi ada sebagian lagi berpendapat membayar tapi harga masih terjangkau oleh remaja. Faktor ekonomi tidak merupakan hambatan bagi remaja karena untuk berkonsultasi mereka tidak membayar, seperti penuturan informan berikut ini:

“......saya pernah datang untuk konsultasi ke puskesmas, waktu itu saya membayar karena harus nebus obat tapi nggak mahal kok buk....." (IP1)

“......saya nggak pernah memanfaatkan klinik remaja buk.... tapi informasi yang saya dengar nggak membayar untuk datang dan berkonsultasi....." (IL1)

".....waktu itu petugas puskesmas datang ke sekolah, untuk mensosialisasikan klinik remaja yang ada di puskesmas, mereka mengatakan bahwa untuk mengunjungi klinik remaja yang ada di puskesmas tidak dipungut bayaran alias gratis....." (IP2) “....sebenarnya untuk datang ke klinik remaja tidak membayar buk....., kita disanakan hanya konsultasi ataupun curhat saja dengan petugas mengenai masalah kita......, tetapi apabila ada penyakit yang yang perlu di obati maka petugas nanti akan memberikan resep kepada kita untuk ditebus...., itupun harganya sebesar harga karcis puskesmas buk...."(IL2)

e. Persepsi Remaja Berdasarkan Faktor Psikososial yang Menghambat Pemanfaatan Pelayanan Kesehatan Reproduksi

Pada faktor psikososial bahwa mayoritas remaja (71\%) mempunyai rasa malu untuk memanfaatkan pelayanan kesehatan reproduksi, karena remaja mempunyai persepsi bahwa pelayanan kesehatan reproduksi yang ada di puskesmas dimanfaatkan untuk remaja yang bermasalah. Remaja juga mempunyai rasa ketidak percayaan kepada petugas terhadap kerahasiaan masalah yang mereka sampaikan (60\%).

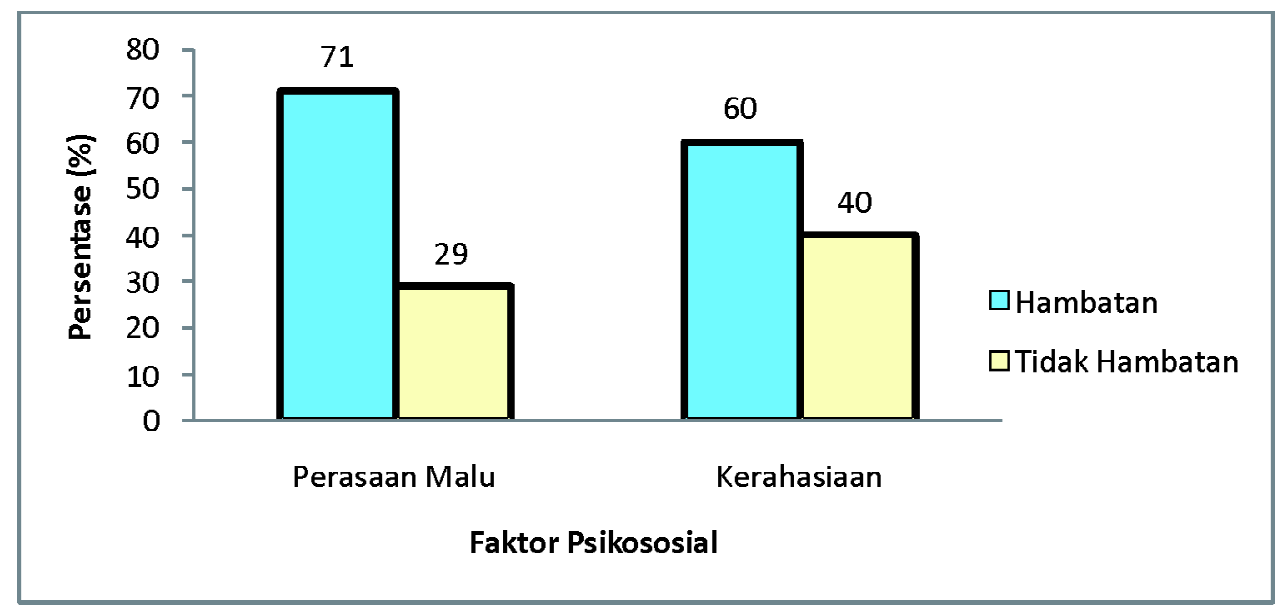

Gambar 4. Distribusi persepsi remaja berdasarkan faktor ekonomi sebagaipenghambat pemanfaatan pelayanan kesehatan reproduksi

Pada Gambar 5 dapat dilihat rata-rata persepsi remaja terhadap faktor penghambat pemanfaatan pelayanan kesehatan reproduksi di puskesmas. 


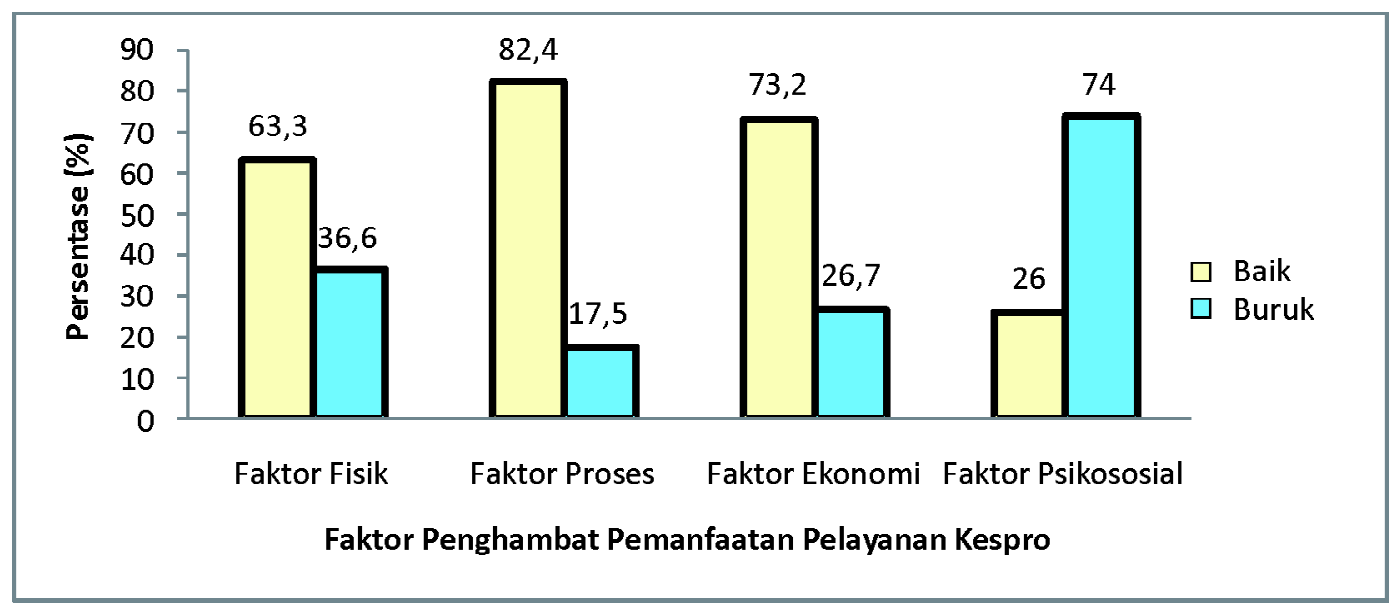

Gambar 5. Persepsi remaja berdasarkan faktor penghambat pemanfaatan pelayanan kesehatan reproduksi

Mayoritas responden mempunyai persepsi yang baik terhadap faktor fisik, faktor proses dan faktor ekonomi sebagai faktor penghambat dalam pemanfaatan pelayanan kesehatan reproduksi. Faktor psikososial dipersepsi sebagai penghambat oleh lebih dari separuh remaja (74\%) untuk memanfaatkan pelayanan kesehatan reproduksi.

Remaja juga mengakui bahwa kesehatan reproduksi itu juga penting diketahui oleh remaja, ketika ditanya lebih lanjut tentang apa yang menjadi pertimbangan dalam memanfaatkan pelayanan kesehatan reproduksi di puskesmas, remaja berpendapat bahwa sebaiknya pelayanan kesehatan reproduksi remaja tersebut yang menjadi konselornya adalah teman sebaya. Remaja juga mengungkapkan bahwa mereka lebih nyaman untuk membicarakan masalah mereka dengan teman dari pada dengan petugas kesehatan, karena menurut mereka petugas kesehatan adalah orang lain yang tidak mengenal bagaimana remaja, remaja juga mengkhawatirkan kerahasiaan masalah yang mereka ungkapkan dan adanya rasa malu bila bertemu dengan petugas yang mengetahui masalah atau tempat mereka mengungkapkan masalah.

".....saya belum pernah datang ke klinik remaja yang ada di puskesmas, saya lebih senang membicarakan masalah saya dengan teman, apalagi sekarang kan ada peer counselor yang dapat membantu masalah saya...dan saya juga meragukan kerahasiaan masalah saya akan terjamin" (IP2)

".......alasan saya tidak mau datang ke klinik remaja yang ada di puskesmas karena saya merasa malu untuk menyampaikan masalah saya, karena saya tidak merasa dekat dengan petugas yang ada dipuskesmas....dan petugasnya kan juga belum tau bagaimana perasaan kita....dan belum tentu buk... petugasnya merahasiakan apa yang kita sampaikan.....kan nanti kita jadi malu kalau ketemu lagi dengan petugas puskesmas"(IL1)

Menurut pendapat informan yang berasal dari peer counselor, bahwa remaja tidak mau memanfaatkan pelayanan kesehatan reproduksi di puskesmas disebabkan karena merasa tidak terjamin kerahasiaan dan juga remaja merasa tidak nyaman menyampaikan masalahnya kepada orang yang tidak begitu kenal dengan mereka dan remaja juga merasa bahwa petugas belum tentu tahu apa yang mereka rasakan, seperti penuturan kedua peer counselor berikut ini:

"..... menurut saya mengapa teman-teman tidak mau memanfaatkan klinik remaja yang ada di puskesmas karena mereka lebih nyaman konsultasi dengan teman saja, kalau 
dengan petugas kesehatan yang ada diklinik remaja sepertinya tidak bisa mengungkapkan masalah mereka..... Salah satu alasannya begini buk...karena kita kan nggak saling kenal, bisa jadi dia kan nggak tau perasaan remaja itu seperti apa....."(IL2)

"....walaupun saya seorang peer counselor buk... tapi saya sendiri juga merasa malu untuk ngomongin masalah saya ke petugas puskesmas karena saya merasa nanti masalah yang saya sampaikan diketahui oleh petugas lain atau juga diketahui oleh guru di sekolah....., nanti kalau ketemu dengan petugasnya saya kan malu buk...selama ini kalau saya ada masalah saya lebih nyaman membicarakannya dengan peer counselor yang lain." (IP1)

Lebih lanjut ditanyakan bagaimana sebaiknya agar klinik remaja dapat dimanfaatkan oleh semua remaja, dan pelayanan kesehatan reproduksi dapat terus berjalan dengan baik, tanpa adanya perasaan malu, takut dan bisa mempercayai bahwa kerahasiaan terjamin. Menurut pendapat informan sebaiknya pelayanan kesehatan reproduksi untuk remaja tetap dapat dilakukan tetapi tidak harus bertemu atau bertatap muka, bisa dilakukan konsultasi lewat radio ataupun lewat SMS. Saran dari informan yang berasal dari peer counselor adalah sebaiknya klinik remaja tetap berjalan tetapi petugasnya bukan petugas puskesmas, sebaiknya adalah peer counselor karena remaja akan lebih nyaman menyampaikan masalah mereka dengan teman sebayanya, berikut penuturannya:

"...ehm...sebaiknya konsultasi tidak harus dalam bentuk langsung bertatap muka... Tapi kita kan bisa konsultasi lewat SMS, ataupun melalui siaran langsung radio....mungkin itu akan lebih banyak dimanfaatkan oleh remaja buk...."(IP2)

"....kalau pendapat saya untuk tempat boleh saja tetap dipuskesmas buk.... Asalahkan petugas yang ada di klinik remaja tersebut bukan petugas puskesmas melainkan seorang peer counselor yang sudah dilatih, agar temanteman merasa nyaman untuk menyampaikan masalah merekan...."(IL2)

".....menurut saya selain tempatnya di puskesmas, hendaknya ada lagi tempat atau cabang dari puskesmas yang berada di luar puskesmas sehingga teman-teman bisa memilih mau mengunjungi, bila mereka malu ke puskesmas mereka bisa datang ke tempat lainnya..... yang dicabang ini sebaiknya tidak petugas puskesmas buk... Tetapi peercounselor..... pihak puskesmas tetap memantau kegiatan tersebut... saya yakin kegiatan seperti ini akan berhasil....."(IP1)

\section{Faktor Fisik Sebagai Penghambat Remaja dalam Memanfaatkan Pelayanan Kesehatan Reproduksi di Puskesmas}

Dari hasil penelitian menunjukkan bahwa remaja berpersepsi bahwa faktor fisik bukan penghambat pemanfaatan pelayanan kesehatan reproduksi di puskesmas (63,3\% persepsi baik). Hal ini didukung dengan kondisi bahwa mayoritas remaja bertempat tinggal tidak jauh dari tempat pelayanan kesehatan reproduksi yaitu dari karakteristik responden diketahui bahwa mayoritas jarak tempuh dari rumah remaja ke pelayanan kesehatan $<1 \mathrm{~km}(43 \%)$. Waktu tempuh yang dibutuhkan $<15$ menit dan dilalui transportasi umum tidak lebih dari 30 menit.

Hasil kuantitatif ini didukung oleh data wawancara mendalam, bahwa remaja mengatakan tidak ada masalah jarak atau waktu tempuh antara tempat tinggal mereka ke pelayanan kesehatan reproduksi yang ada di puskesmas. Remaja juga menyampaikan bahwa rata-rata mereka tinggal tidak jauh dari puskesmas dan walaupun jauh para remaja mempunyai kendaraan untuk transportasi menuju ke pelayanan kesehatan reproduksi.

Penelitian ini berbeda dengan sikap remaja terhadap pelayanan kesehatan reproduksi di Islandia, 
bahwa jarak, transportasi dan keterjangkauan biaya berpengaruh signifikan terhadap pemanfaatan pelayanan kesehatan reproduksi remaja. Remaja tidak memanfaatkan pelayanan kesehatan reproduksi karena jarak pelayanan yang jauh dari tempat tinggal mereka. Sebaliknya, remaja yang pernah memanfaatkan pelayanan kesehatan reproduksi karena pelayanan dekat secara geografis. Sekitar $80 \%$ dari semua responden mengatakan bahwa akan sangat penting bahwa pelayanan kesehatan reproduksi dekat dengan tempat tinggal mereka. ${ }^{9}$

Penelitian ini bertentangan dengan hasildi Addis Ababa bahwa remaja tidak mau memanfaatkan pelayanan kesehatan reproduksi bila pelayanan tersebut berada dekat dari tempat tinggal mereka, sehingga mereka takut untuk mengunjungi pelayanan dengan alasan takut diketahui oleh orang tua atau orang-orang yang mereka kenal. ${ }^{7}$

\section{Faktor Proses sebagai Penghambat Remaja dalam Memanfaatkan Pelayanan Kesehatan Reproduksi di Puskesmas}

Mayoritas remaja mempunyai persepsi yang baik terhadap proses pelayanan ( $82,4 \%)$, yang berarti pelayanan yang diberikan sudah menerapkan konsep youth friendly yaitu sikap petugas yang ramah dan bersahabat dengan remaja. Remaja juga mempunyai persepsi bahwa untuk mendapatkan pelayanan mereka tidak dipersulit, sebagai mana yang dituturkan remaja pada wawancara mendalam. Remaja mengatakan bahwa petugas yang ada di klinik remaja tersebut cukup ramah dan baik, mereka merasakan hal tersebut saat petugas berkunjung ke puskesmas untuk memberikan informasi mengenai kesehatan reproduksi, remaja juga mengatakan bahwa untuk mendapatkan pelayanan di puskesmas mereka tidak menjalani prosedur yang berbelit-belit.

Penelitian ini berbeda dengan pendapat bahwa salah satu hambatan remaja untuk memanfaatkan pelayanan kesehatan reproduksi adalah karena pelayanan yang tidak bersahabat (youth friendly), dan salah satu program yang dilakukannya untuk memperbaiki pelayanan kesehatan reproduksi adalah melaksanakan pelayanan yang bersahabat dan mengutamakan kerahasiaan. ${ }^{7}$ Pemanfaatan pelayanan kesehatan reproduksi remaja yang sudah menggunakan konsep youth friendly biasanya lebih tinggi, tapi pada penelitian ini remaja mempunyai alasan mengapa mereka tidak mau memanfaatkan pelayanan tersebut disebabkan mereka masih mengganggap bahwa petugas adalah seseorang yang baru mereka kenal dan tidak bisa untuk menyampaikan atau menceritakan masalah mereka secara terbuka.

Dari penelitian menyatakan bahwa untuk dapat meningkatkan pemanfaatan pelayanan kesehatan reproduksi remaja, salah satunya adalah melatih peer counselor sehingga remaja dapat menyampaikan atau menceritakan masalah mereka kepada konselor sebaya secara terbuka. Remaja lebih percaya kepada teman sebayanya karena mereka menganggap bahwa teman adalah orang terdekat dan orang yang paling mengerti dengan keadaannya sekarang. ${ }^{8}$

\section{Faktor Ekonomi Sebagai Penghambat Remaja dalam Memanfaatkan Pelayanan Kesehatan Reproduksi di Puskesmas}

Pada penelitian ini faktor ekonomi tidak dipersepsi sebagai pengahambat oleh 73,2\% remaja, karena untuk mendapatkan pelayanan kesehatan reproduksi remaja tidak perlu mengeluarkan biaya yang besar. Remaja mengatakan bahwa untuk mendapatkan pelayanan kesehatan reproduksi mereka tidak membayar, jikapun membayar untuk hal-hal tertentu mereka mengatakan masih terjangkau. Pertimbangan biaya menentukan remaja untuk akses ke pelayanan kesehatan reproduksi, ternyata biaya tidak menjadi hambatan remaja untuk memanfaatkan pelayanan kesehatan reproduksi yang ada di puskesmas.

Berbeda dengan penelitian yang dilakukan di Amerika Serikat, akses remaja tergantung sejauh mana mereka memiliki cakupan asuransi kesehatan. Hampir 70\% remaja mengatakan biaya harus lebih 
murah untuk mendapatkan pelayanan kesehatan reproduksi, 50\% remaja memandang hal ini sangat penting agar pelayanan kesehatan reproduksi bebas biaya. ${ }^{10}$ Penelitian yang lain bahwa $80 \%$ remaja menginginkan pelayanan kesehatan reproduksi remaja hendaknya murah atau sama sekali gratis. ${ }^{7}$

\section{Faktor Psikososial Sebagai Penghambat Remaja dalam Memanfaatkan Pelayanan Kesehatan Reproduksi di Puskesmas}

Faktor psikososial dipersepsi sebagai hambatan memanfaatkan pelayanan ( $74 \%$ remaja), hal ini juga dikuatkan dengan hasil wawancara mendalam. Pada umumnya remaja mengaku tidak mau memanfaatkan pelayanan kesehatan reproduksi yang ada di puskesmas disebabkan karena adanya rasa keengganan dalam menyampaikan masalah kepada petugas yang dianggapnya sebagai orang yang baru dikenal. Penelitian ini senada dengan penelitian mengenai persepsi remaja terhadap pelayanan kesehatan reproduksi, yaitu $72 \%$ remaja tidak memanfaatkan pelayanan kesehatan reproduksi disebabkan adanya perasaan malu, takut dengan orang tua dan masyarakat. ${ }^{7}$

Sebenarnya remaja berharap bahwa teman sebaya atau orang tua bisa dijadikan tempat mereka untuk menceritakan masalah mereka. Sebagaimana penelitian tentang remaja mempunyai perasaan tidak nyaman dan malu untuk mengungkapkan permasalahannya kepada petugas yang ada di pelayanan kesehatan reproduksi remaja, mereka lebih memilih membicarakan dengan teman sebayanya ataupun dengan orang tua mereka sendiri. $^{3}$

Penelitian yang dilakukan di 5 kota di Indonesia tentang pemanfaatan pelayanan kesehatan reproduksi remaja terhadap 2.479 remaja yang berusia $15-24$ tahun, hanya $23,42 \%$ yang pernah memanfaatkan pelayanan kesehatan reproduksi remaja walaupun $94,56 \%$ remaja menyatakan tahu adanya pelayanan. Remaja juga membutuhkan suatu pusat pelayanan kesehatan reproduksi untuk mengatasi persoalan sehari-hari. ${ }^{11}$ Penelitian ini didukung juga oleh pengakuan responden dalam wawancara mendalam, bahwa sesungguhnya remaja membutuhkan pelayanan kesehatan reproduksi untuk mengatasi masalah-masalah yang mereka hadapi.Namun yang menjadi hambatan bagi remaja adalah perasaan tidak nyaman dan merasa tidak leluasa untuk menyampaikan masalah kepada petugas yang ada diklinik remaja tersebut. Remaja merasa lebih nyaman menyampaikan masalah dengan teman sebayanya atau dengan peer counselor yang ada disekolah. Sebagian remaja mau mendiskusikan dengan petugas tetapi tidak bertemu langsung dengan petugas hanya melalui telepon atau sms karena mereka tidak ingin identitas mereka diketahui dengan alasan malu jika ketemu dengan petugas kesehatan setelah konsultasi.

Menurut penelitian yang lain bahwa untuk dapat meningkatkan pemanfaatan pelayanan kesehatan reproduksi remaja, salah satunya adalah melatih peer counselor sehingga remaja dapat menyampaikan atau menceritakan masalah mereka kepada konselor sebaya secara terbuka. Remaja lebih percaya kepada teman sebayanya karena mereka menganggap bahwa teman adalah orang terdekat dan orang yang paling mengerti dengan keadaannya sekarang. ${ }^{8}$

Menurut WHO (2001), pendidik/konselor sebaya diperlukan karena: 1) mereka menggunakan bahasa yang hampir sama sehingga informasi mudah dipahami oleh sebayanya, 2) remaja lebih terbuka mengemukakan pikiran dan perasaannya kepada pendidik/konselor sebayanya, 3) pesan-pesan sensitif dapat disampaikan secara terbuka. Strategi peer education/peer counselor, selain dapat meningkatkan kepedulian atau kewaspadaan ternyata dapat mendukung terjadinya perubahan perilaku.

\section{KESIMPULAN DAN SARAN}

Berdasarkan analisis dan pembahasan yang telah diuraikan oleh peneliti, dapat diambil kesimpulan bahwa: (1) hambatan remaja dalam memanfaatkan pelayanan kesehatan reproduksi yang ada di puskesmas disebabkan oleh hambatan 
psikososial, dimana adanya stigma bahwa pelayanan kesehatan reproduksi adalah pelayanan bagi remaja yang bermasalah. Hambatan lain juga disebabkan karena remaja tidak mempercayai terjaminnya kerahasiaan terhadap masalah yang mereka sampaikan, (2) remaja mempunyai persepsi bahwa faktor fisik (jarak dari tempat tinggal ke pelayanan kesehatan reproduksi di puskesmas), faktor proses (pelayanan dengan konsep youth friendly dan kemudahan dalam mendapatkan pelayanan) dan faktor ekonomi (biaya pelayanan), bukan merupakan faktor penghambat pemanfaatan pelayanan kesehatan reproduksi yang ada di puskesmas.

\section{DAFTAR PUSTAKA}

1. WHO. Adolescents Friendly Health Services in The South-East Asia Region. 2004.

2. BPS B, Depkes, . Survei kesehatan reproduksi remaja Indonesia 2007 Macro International. Calverton, Maryland, USA. International BM, editor2008.

3. Tegegn A, Yazachew, M., Gelaw, Y. Reproductive health knowledge and attitude among adolescent: an community based study in Jimma Town, Southwest Ethiopia. Ethiop J Health Dev. 2008;22 (3):23451.

4. Sinjunjung DKK. Profil Kesehatan Kabupaten Sijunjung Tahun 2008.
5. Belmonte G, Magnani, \& Lipovsek. Wasington. DC. Barriers to adolescents use of reproductive health services in three Bolivian cities, FOCUS on Young Adults. 2000.

6. Koster A, Kemp, J., Offei, A. . Utilization of reproductive health services by adolescent boy in the eastern region of Ghana. Afr J Reprod Health. 2001;5(1):409.

7. Berhane F, Berhane, Y. \& Fantalun, M. 19(1):29-36. Adolescents' Health Services Utilization Pattern and Preferences: Consultation for Reproductive Health Problems and Mental Stress are Less Likely. Ethiop J Health Dev. 2005;19(1):29-36.

8. Mmari KN, Magnani, R.J. . Does making clinic-based reproductive health services more youth-friendly increase services use by adolescents? evidence from Lusaka, Zambia. J Adolesc Health. 2003;33: 259-70.

9. Bender BSS. Attitudes of Icelandic Young People TowardSexual and Reproductive Health Services. Family Planning Perspectives. 1999;31(6).

10. Long LH, Roberta., Baron H, Cassidy AM, Whittaker PG. Access to adolescent reproductive health services: financial and structural barriers to care2003 Available<http://www.ugi-usa.org/pubs/ journals> [diakses 9 September 2009].

11. Tanjung A, Utamadi, G., Sahajana, J. \& Tafal, Z. . Kebutuhan akan informasi dan pelayanan kesehatan reproduksi remaja. Laporan need assessment di Kupang, Palembang, Singkawang, Cirebon dan Tasikmalaya. Jakarta: BKKBN \& UNFPA.; 2001. 